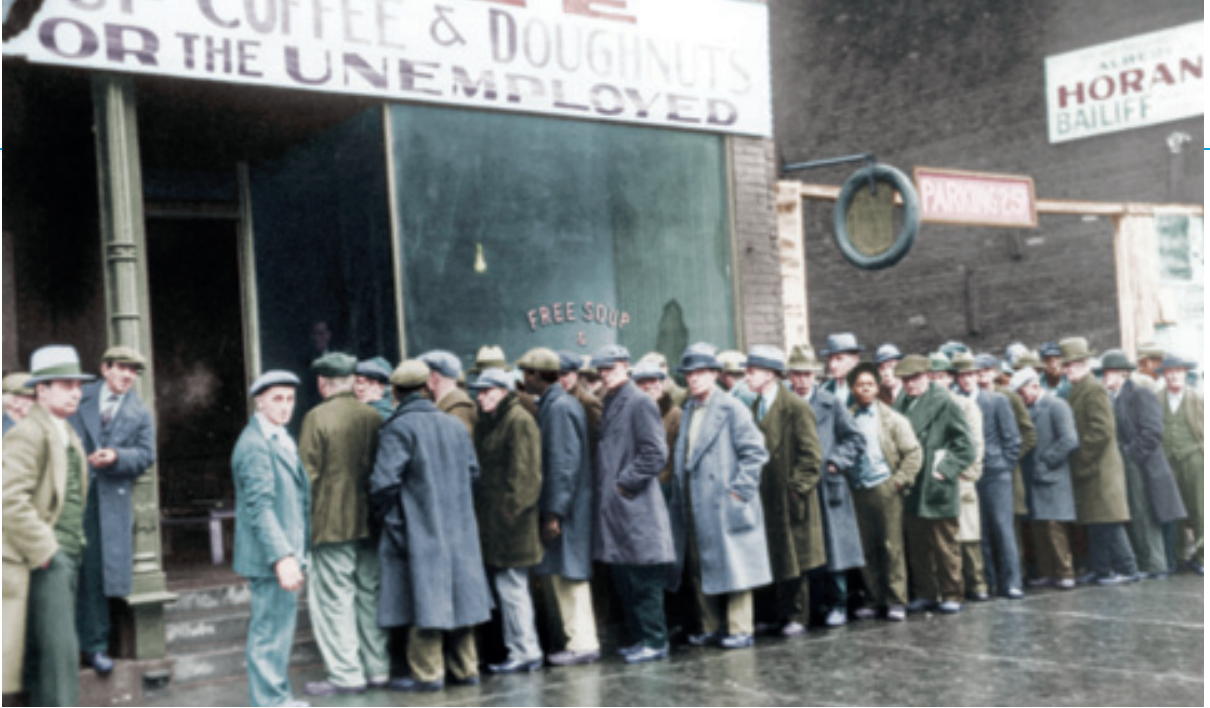

Chicago 1931. Illustrasjonsfoto @ akg-images/SCANPIX

\title{
Bedre helse i nedgangstider?
}

\author{
En analyse av historiske data viser at \\ forventet levetid i USA steg med seks \\ år fra 1929 til 1933 til tross for de \\ $\emptyset$ øonomiske nedgangstidene.
}

Det var krise i verdensøkonomien i begynnelsen av 1930-årene, og nedgangstider kan ha effekt på folkehelsen. Amerikanske forskere har nå undersøkt hvordan forventet levetid og mortalitet var assosiert med økonomien i perioden 1920-40 (1).

Forskerne utførte deskriptive analyser, og så etter assosiasjoner mellom endringer $\mathrm{i}$ helseindikatorer og årlige endringer i økonomisk aktivitet. De fant at folkehelsen bedret seg i årene 1930-33, med en fallende mortalitet i nesten alle aldersgrupper og en økning i forventet levetid for både kvinner, menn, hvite og ikke-hvite amerikanere. Mortaliteten var høyest $\mathrm{i}$ årene med sterkest økonomisk vekst.

- I alle vestlige land økte levealderen sterkt på 1900-tallet. Det gjaldt også i mellomkrigstiden. Men det er viktig å huske at en sammenheng mellom levealder og økonomiske nedgangstider er faseforskjøvet i betydelig grad, altså at økningen i levealderen i 1930-årene i stor grad var resultat av levekårsforbedringer flere år tidligere, sier professor Steinar Westin ved Institutt for samfunnsmedisin, Norges teknisk-naturvitenskapelige universitet. - Det er heller ikke bare dødelighet som er av interesse i denne sammenhengen (2). For eksempel arbeidsledighet kan avleses i mål for legesøkning, sykmeldinger og uførepensjoner. Økonomiske nedgangstider er altså ikke sunt, sier Westin.

\section{Åslaug Helland}

ahelland@gmail.com

Tidsskriftet

\section{Litteratur}

1. Granados JA, Roux AV. Life and death during the Great Depression. Proc Natl Acad Sci USA 2009: 106: $17290-5$

2. Westin S. Finanskrisens betydning for folkehelsen Tidsskr Nor Legeforen 2009; 129: 1621
Total sekvensering ga viktig klinisk informasjon

Amerikanske forskere har sekvensert et komplett genom fra en frisk 40 år gammel mann og konstaterer at de har fått frem relevant klinisk informasjon fra sekvenseringen. Forsøkspersonen er Stephen Quake, professor i bioteknikk ved Stanford University (Lancet 2010; 375: 1525-35).

Forskerne sekvenserte Quakes genom og sammenliknet det med en database med resultatene fra hundrevis av genetiske studier og ca. 2,6 millioner enkeltnukleotidpolymorfismer. Det viste seg at forsøkspersonen hadde betydelig økt risiko for type 2-diabetes, og det ble beskrevet økt risiko for klopidogrelresistens, plutselig hjertedød og prostatakreft, men lavere risiko for Alzheimers sykdom.

Feltet personlig genomikk innebærer vanskelige etiske vurderinger. Forskerne håper at det kan åpne for mer skreddersydd behandling, og at feltet kommer til å være utbredt i klinisk praksis i løpet av ti år.

\section{Kan man bli god kirurg i Europa?}

Det er stor forskjell $i$ arbeidstid mellom kirurger i Europa (48 timer per uke) og Nord-Amerika (80 timer). Det er uklart om denne store forskjellen påvirker kirurgenes kompetanse.

Med tre validerte tester for klinisk kompetanse sammenliknet man ferdigutdannede kirurger i Nederland og Canada. Hypotesen var at de som hadde lang arbeidstid, ville prestere signifikant bedre enn de andre (Br J Surg 2010; 97: 443-9).

Det var ingen forskjeller mellom kirurgene med henblikk på kunnskap, kliniskanalytiske evner og tekniske ferdigheter, men de kanadiske kirurgene skåret signifikant bedre på kompliserte oppgaver og kommunikasjonsferdigheter.

\section{Antibiotika ved kroniske infeksjoner bør varieres}

\section{Antibiotikabehandling av infeksjoner i urinveiene og luftveiene kan føre til resistensutvikling på individnivå i inntil 12 måneder.}

Hoveddelen av forskrivningen av antibiotika skjer i allmennpraksis, og det er økende frykt for at vanlig forekommende infeksjoner blir vanskeligere å behandle på grunn av antibiotikaresistens. Engelske forskere har foretatt en metaanalyse for å undersøke påfølgende antibiotikasresistens hos personer som har fătt forskrevet antibiotika i allmennpraksis (1).

Analysen inkluderte 19 observasjonsstudier og fem randomiserte studier. I fem studier av bakterier i urinveiene var sammenslått oddsratio for resistens $2,5(95 \% \mathrm{KI}$
2,1-2,9) innen to måneder etter behandling og 1,3 (1,2-1,5) innen 12 måneder. I sju studier av bakterier i luftveiene var OR for de tilsvarende periodene $2,4(1,4-3,9)$ og $2,4(1,3-4,5)$. Studier viste at lengre og oftere behandling var assosiert med høyere resistensrate. Det var ingen konsistente resultater ved sammenlikning av potensialet til forskjellige typer antibiotika med henblikk på å indusere resistens.

- Dette er viktig oppsummering av gjeldende kunnskap på feltet, sier professor Morten Lindbæk, leder for Antibiotikasentret for primærmedisin. Det dokumenterer at resistens ikke bare er et problem på populasjonsnivå, men også for enkeltpasienter. Det er overraskende at resistensen opprettholdes over så lang tid.
- Oppsummeringen vil også ha klinisk betydning for antibiotikabehandling i allmennpraksis, særlig for den lille gruppen av pasienter som trenger langtidsbehandling ved kroniske urinveis- og luftveisinfeksjoner. For disse vil det være et sterkt argument for å skifte antibiotika med jevne mellomrom, avslutter Lindbæk.

\section{Trine B. Haugen}

trine.b.haugen@hf.hio.no

Tidsskriftet

\footnotetext{
Litteratur

1. Costelloe C, Metcalfe C, Lovering A et al. Effect of antibiotic prescribing in primary care on antimicrobial resistance in individual patients: systematic review and meta-analysis. BMJ 2010; 340 c2096.
} 